JINOTEP Vol 7 (2) (2020): 86-95

DOI: $10.17977 /$ um031v7i22020p086

JINOTEP (Jurnal Inovasi Teknologi Pembelajaran)

Kajian dan Riset Dalam Teknologi Pembelajaran

http://journal2.um.ac.id/index.php/jinotep/index

\title{
GAMIFIED BALINESE LOCAL STORIES EFFECT AS A TEACHING MEDIA TOWARDS YOUNG LEARNERS' SPEAKING SKILL
}

\author{
Ida Ayu Fortuna Ningrum, Putu Kerti Nitiasih, Luh Gd Rahayu Budiarta
}

Universitas Pendidikan Ganesha - Singaraja, Indonesia

\section{Article History}

Received:20-04-2020

Accepted: 15-05-2020

Published: 1-10-2020

\section{Keywords}

Gamified; Balinese local stories; Speaking skill

\begin{abstract}
Abstrak
Penelitian ini bertujuan untuk mencari tahu efek dari gamifikasi cerita lokal Bali sebagai media belajar terhadap keterampilan berbicara Bahasa Inggris untuk pelajar usia dini. Kuasi-eksperimental dengan desain one group pre-test post-test diterapkan sebagai metode penelitian. Seluruh siswa SD Negeri 4 Kaliuntu menjadi populasi penelitian ini sedangkan sampelnya yaitu 38 siswa kelas 5 pada tahun akademik 2019/2020. Adapun 3 instrumen yang digunakan meliputi gamifikasi berdasarkan cerita lokal Bali sebagai instrumen perlakuan, tes keterampilan berbicara sebagai instrumen pretest-posttest dan rubrik penilaian berbicara. 5 dimensi keterampilan berbicara dijadikan landasan pembuatan rubrik penilaian. Pretest dan posttest diberikan kepada grup eksperimental sebanyak 6 kali secara berulang. Setelah diberikan perlakuan, skor rata-rata posttest siswa lebih tinggi $(79,95)$ dibandingkan skor rata-rata pretest $(69,97)$. Hasil dari paired sample t-test menunjukkan bahwa Sig (2-tailed) adalah .000 yang menunjukkan adanya efek signifikan dari penggunaan gamifikasi cerita lokal Bali sebagai media pengajaran pada keterampilan berbicara pelajar usia dini.
\end{abstract}

\begin{abstract}
This study was aimed to find out the effect of gamified Balinese local stories as teaching media towards young learners' speaking skills in English. Quasiexperimental with one group pretest-posttest design was implemented as the method of this research. All of the students of SD Negeri 4 Kaliuntu became the population of this study, while the sample was 38 fifth grade students in the academic year of 2019/2020. There were three instruments in this research that included gamified Balinese local stories as the treatment instrument, speaking test as the pretestposttest instrument, and speaking rubric. Five dimensions of speaking skills were inserted in the speaking rubric. Pretest and posttest were given to the experimental group for six times repeatedly. After being treated, the average score of students' posttests was higher (79.95) than the average score of pretests (69.97). Also, the result of the paired sample t-test revealed that the value of Sig (2-tailed) is .000 which implied that there was a significant effect of gamified Balinese local stories as teaching media towards young learners'speaking skills.
\end{abstract}

Corresponding author :

Adress: Jalan Merak No.26 Singaraja, Kec. Buleleng, Kab. Buleleng,

2020 Universitas Negeri Malang p-ISSN 2406-8780 e-ISSN 2654-7953

Bali, Indonesia

Instansi: Universitas Pendidikan Ganesha

E-mail: idaayufortunaningrum@gmail.com 


\section{INTRODUCTION}

The technology innovation in the $21^{\text {st }}$ century undoubtedly changes education today. It is in line with the recent situation in which the learners nowadays are categorized as digital natives. 'Digital Natives' or widely known as 'Generation $Z$ ' are the generations who were born between 1995- 2012 and they are familiar with digital things and socially matured following the advent of technology innovation (Singh, 2014; Stickel, 2017) Meanwhile, according to (Riegel \& Mete, 2017), teachers, who are categorized as digital immigrants as they were born and grew up before the introduction of technological advancement, are saddled with the responsibility of exploring creative ways to enhance students' academic performance. This $21^{\text {st }}$ century demands the appliance of innovative teaching media by incorporating technology as learning tools.

In addition, students nowadays essentially need "4Cs" skills in this $21^{\text {st }}$ century education including communication. Students are required to master English as the primary means for global communication in order to survive in this era where communication skill is needed. Moreover, the school-based English learning curriculum is focused on the functional, transactional, and interactional viewpoint of the target language existence since the middle of 2013 (Mattarima, 2011). Accordingly, this program does not only stresses on what the students should know or understand about the language but also about how they can use it. It is supported by Gudu (2015) which stated that the success of learning a foreign language is determined from the ability to participate in a conversation of that language. Mastering the art of speaking will reflect a high degree of comprehension for other skills such as reading, listening and writing (Leong \& Ahmadi, 2017). Thus, teaching how to speak in English as a foreign language context has become progressively crucial.

However, the learning process of English does not take place as planned by the program that insists the students to actively engage and participate in the classroom by speaking practice. The majority of Indonesian
EFL students are passive in the teaching and learning process of English (Mattarima, 2011). The reasons of this problem are explained by the theory from Ur (1996) which claimed that the difficulties of speaking English as foreign language arise because the students are too concerned about making errors and receiving teacher's critique. They frequently lack the courage to convey themselves because of the teaching method. From the preliminary observation done in SD Negeri 4 Kaliuntu, it was noticed that the students there also experienced the same problems. The textbook and worksheet are still used as the teaching media. Also, the students infrequently listen and practice the the words' pronunciation. It causes the students feel uninterested and less engaged with the learning process.

To surmount those issues, the teaching methods of speaking for young learners require much attention as Cameron (2002) discovered that teaching how to speak English to young learner is more effective than teaching to older learner as they have a stronger aptitude to understand and mimic the new words pronunciation that they have learned. The ability of young learners is exactly like a sponge, they can quickly grasp new language (Derakhshan \& Davoodi Khatir, 2015). Those who are 5-12 years old are considered as young learners (Bakhsh, 2016). As a teacher for young learners, considering their characteristics is a must. Bakhsh (2016) mentioned that children all over the world have the same fundamental characteristics such as love to play while they are learning. It is better for students to not learn in demanding conditions as they can quickly be unfocused and unhapppy. They will quickly forget about what they have learned because they do not relish the learning process. So, the teacher should design and implement a joyful yet meaningful learning environment for the children to become involved and participate in the learning process.

By concerning to the learners' issues, and also realizing that young learners nowadays are considered as digital natives with the same fundamental characteristic, the integration of material and technology can be 
88 JINOTEP (Jurnal Inovasi dan Teknologi Pembelajaran) Kajian dan Riset dalam Teknologi Pembelajaran Vol.7, No.2, Oktober 2020, Hal.86-95

an attractive and pleasant learning media for speaking skill. Gamification is one of the alternative teaching media regarding to the integration of material and technology. Gamification is an aesthetic media with game-based mechanics and game thinking that aimed to connect people, inspire action, encourage learning and improve problemsolving skill of the students (Mert \& Samur, 2018; Zichermann \& Cunningham, 2011) Gamification facilitates enjoyable and interesting learning as it is accompanied by vivid visuals and the games audio (Setiawan et al., 2019). Consequently, they will read the story in an entertaining way and mimic each word pronunciation. It will make the students acquire more vocabularies as it encourages language learning and makes the students more comfortable (Taghizadeh et al., 2015). The more they gain the vocabularies, the more they can comprehend the text (Mohseni Takaloo \& Ahmadi, 2017). Therefore, gamification is a suitable method as it is in accordance with the essence of the comprehension of young learners that does not come just from an explanation, but also from what they look, listen, and have an opportunity to touch and communicate with (Lee, 2015).

The material used in gamification for education should be amusing as well as educating. Local story is one of a proper material that can be created in gamification. Local story can be said as a cultural manifestation that emerged and cultivated from traditional people. Local story can be used to help young learners in understanding English authentically as it has strong relationship with their prior knowledge about their hometown (Imaniah, Nargis, \& Tangerang, 2017). Local story is preferred as a good content since it is a narrative style and it displays a number of moral values that students can perceive and implement in their daily life. Nitiasih et al., (2020) has established gamification focused on several Balinese local stories such as I Ketimun Mas, I Cupak and Gerantang, Manik Angkeran, Siap Selem, and Sugih and Tiwas. Those five stories were applied in this continual present study.
Several related studies have been conducted to find out the effectiveness of gamification. A research by García \& Alvaro (2017) entitled "Gamification In English Teaching In Primary Education" found that gamification can effectively produce positive outcomes in language teaching as it deals with many issues including commitment, involvement, and motivation. Gamification is an creative and valuable media a foreign language learning process. A study conducted by Mekler, et al. (2017) entitled "Towards Understanding the Effects of Individual Gamification Elements On Intrinsic Motivation and Performance" also discovered that gamification can raise the motivation and performance of the students in the classroom.

On the other hand, there is no research on the use of gamified Balinese local stories to enhance young learner's speaking skill. For this reason, it is important to carry out this research in order to decide whether gamified Balinese local stories can be an effective media in teaching young learners' speaking skill. SD Negeri 4 Kaliuntu was chosen as the place to conduct this present study, specifically for the fifth-grade students. Therefore, Balinese local stories as the content of gamification and speaking skill as the measured skill became the novelties of this study.

\section{METHOD}

\section{Design and Materials}

In this study, one group pretestposttest design was applied. It is one of the design of quasi-experimental which has two features. First, there was no comparative control group as this design only involves a sole group with a sole condition. A sole condition denotes that the same treatment and assessments were given to all of the participants in the sole group. Second, the assessment of a dependent variable before and after treatment is required for the implementation of a linear ordering. Pretest and posttest were given to the experimental group for six times repeatedly. Before the treatment, the pretest was given and then after the treatment, the group was given the posttest. The scores of pretests and posttests 
were compared and then the efficacy of the procedures was analyzed quantitatively.

\section{Participants}

This study involved 38 fifth grade elementary school students in the 2019/2020 academic year. Fifth grade was selected because the gamification based on Balinese local story was previously designed and developed for the fifth-grade students. The research sample had accomplished the sample requirement as the experimental study can be carried out if the samples are at least 10.

\section{Instrument}

There were three instruments used in this study including pretest and posttest instrument, treatment instrument and speaking rubric. A speaking test is used as the pretest and posttest instrument. The questions were designed based on the story of gamification and three basic competencies such as 3.3 about identifying the varieties of activities in surroundings, 3.4 about comparing adjectives in a short comparison sentence, and 3.7 about identifying things or pictures based on their shape that can be found in surroundings. Gamified Balinese local stories which was a game handled in an electronic device was implemented as the treatment instrument. This game was played together in the classroom to support their learning particularly their speaking skill. A contextual, attractive, logic and fun learning was provided by this game. Furthermore, the scoring rubric consisted of 5 dimensions of speaking, namely fluency, pronunciation, grammar, vocabulary, and confidence. Several descriptors were consisted in each dimension which weights differently when measuring. Each descriptor differed in terms of score range from 1-5 depending on the success of the students in speaking. Firstly, two examiners tested the content validity of the speaking rubric. Gregory's formula was used to analyze the comparative result of suggestions and revisions from both examiners. Also, Gregory's formula was used to find out the content validity. To put the the result of examination from both experts, a cross-tabulation table was applied. The score of cross tabulation table revealed that the content validity score was 1.00 which rated as very high according to the level of content validity. Hence, the speaking rubric has been accepted and can be used as the instrument in collecting the data.

\section{RESULTS}

The Result of Descriptive Analysis

Table 1. The Average Score Summary of Pretests-Posttest

\begin{tabular}{|c|c|c|c|}
\hline \multirow{3}{*}{$\begin{array}{l}\text { Average } \\
\text { Score }\end{array}$} & Meeting & Pretest & \multirow{2}{*}{$\frac{\text { Posttest }}{66.45}$} \\
\hline & 1 & 56.97 & \\
\hline & 2 & 65.55 & 76.18 \\
\hline & 3 & 70.66 & 80.92 \\
\hline & 4 & 74.74 & 84.47 \\
\hline & 5 & 75.39 & 85.00 \\
\hline & 6 & 76.84 & 86.71 \\
\hline Avera & & 69.97 & 79.95 \\
\hline
\end{tabular}

Table 1 displayed the the summary of the pretests and posttests average score. In six meetings, the experimental group was treated by both pretest and posttest repeatedly. The average score from all the pretests and the average score from all the posttests in each meeting were calculated and summarized.

Table 2. Descriptive Analysis of Pretests and Posttests

\begin{tabular}{lcc}
\hline & Pretest & Posttest \\
\hline Average Score & 69.97 & 79.75 \\
\hline $\begin{array}{l}\text { Standard } \\
\text { Deviation }\end{array}$ & 2.091 & 2.634 \\
\cline { 1 - 1 } Median & 70.00 & 79.58 \\
\hline Max. Score & 75.83 & 85.00 \\
\hline Min. Score & 65.00 & 75.00 \\
\hline Variance & 4.373 & 6.941 \\
\hline
\end{tabular}

From all treatments, the average score of pretest was 69.97 meanwhile the average score of the posttest was 79.75. It revealed that the average score of the posttests was higher than the average score of pretests.

However, a t-test should be done to determine whether the difference of the average score was significant between pretest and posttest. Before that, firstly, the data distribution was analyzed to select the type of t-test that would 
90 JINOTEP (Jurnal Inovasi dan Teknologi Pembelajaran) Kajian dan Riset dalam Teknologi Pembelajaran Vol.7, No.2, Oktober 2020, Hal.86-95

be conducted. The parametric test would be used if the data were distributed normally. On the contrary, a non-parametric test would be conducted if the data were not distributed normally. If the value of KolgomorovSmirnov is higher than .05 , the data was considered as normally distributed.

\section{The Result of Normality Test}

Table 3. The Result of Normality Test

\begin{tabular}{lccc}
\hline \multicolumn{4}{c}{ Kolmogorov-Smirnov $^{\mathrm{a}}$} \\
\hline & Statistic & Df & Sig. \\
\hline $\begin{array}{l}\text { Summary of } \\
\text { Average Score } \\
\text { in Pretest }\end{array}$ & .136 & 38 & .075 \\
& & & \\
\hline $\begin{array}{l}\text { Summary of } \\
\text { Average Score } \\
\text { in Posttest }\end{array}$ & .108 & 38 & .200 \\
\hline
\end{tabular}

Table 3 the result of the normality test which revealed the value of Kolgomorov-Smirnov for the pretest was .075 while for the posttest was .200. The data was considered as normally distributed as the values of Sig. from both pretest and posttest were higher than .05. After that, the paired sample t-test was conducted.

\section{Hypothesis Testing}

To investigate the significant effect of using gamified Balinese local stories as teaching media on students' speaking skill, hypothesis testing was done after after the data were considered as normally distributed. The paired sample t-test was conducted to know the result of hypothesis testing. The result of paired sample t-test can be seen in table 4 .

Table 4. Paired Sample T-test on Pretest and Posttest Score

\begin{tabular}{|c|c|c|}
\hline \multicolumn{3}{|c|}{ Pair 1} \\
\hline & & $\begin{array}{l}\text { Mean } \\
\text { Pretest } \\
\text { Mean } \\
\text { Posttest }\end{array}$ \\
\hline $\begin{array}{l}\text { Paired } \\
\text { Differences }\end{array}$ & Mean & -9.78070 \\
\hline & $\begin{array}{l}\text { Std. } \\
\text { Deviation }\end{array}$ & 1.76175 \\
\hline
\end{tabular}

\begin{tabular}{llll}
\hline & \multicolumn{2}{c}{$\begin{array}{l}\text { Std. Error } \\
\text { Mean }\end{array}$} & \multicolumn{1}{c}{.28579} \\
& $\begin{array}{l}95 \\
\text { Confidence }\end{array}$ & Lower & - \\
& $\begin{array}{l}\text { Interval of } \\
\text { Difference }\end{array}$ & & 10.35977 \\
\cline { 3 - 4 } & & Upper & -9.20163 \\
\hline $\mathrm{T}$ & & & -34.223 \\
\hline $\mathrm{Df}$ & & & 37 \\
\hline $\begin{array}{l}\text { Sig. } \\
\text { tailed })\end{array}$ & $(2-$ & & .000 \\
\hline
\end{tabular}

From the Table 4, it revealed that the value of Sig (2-tailed) was .000 which was lower than .05 . It denoted that there was a significant mean difference between pretest and posttest.

\section{DISCUSSION}

This research was focused on finding out the significant effect of gamified Balinese local stories as a teaching media on young learners' speaking skill of the fifth-grade students in SD Negeri 4 Kaliuntu. Firstly, the researcher selected the sample. A class of fifth grade in SD Negeri 4 Singaraja which consists of 38 students was selected as the sample of the study. Gamified Balinese local stories would be used by the researcher as a teaching media in learning English. A pretest that had been created by the researcher was given to the students before doing the treatment. Researcher asked the students to describe some pictures given related to the topic. Then, the treatment was conducted after all the students had been pretested. As what have been mentioned before, gamified Balinese local stories as a teaching media was functioned as the treatment. Five different gamified Balinese local stories namely Manik Angkeran, I Sugih and I Tiwas, I Cupak and I Grantang, I Ketimun Mas, and Siap Selem was applied by the researcher as a teaching media since the preliminary study had established and developed those gamifications.

Pretest, treatment, and posttest were given in six meetings. In the first meeting, the researcher taught the students based on the basic competency 3.3 which about 
determining the activities in surroundings and the story used was Manik Angkeran. To accomplish basic competency 3.3 too, Tiwas and I Sugih was used in the second day. For the third meeting, the basic competency 3.4 which was about making a short comparison sentence related to adjectives was implemented with the story of I Cupak and I Gerantang. The next day was still about the basic competency 3.4 and the story applied was Manik Angkeran. In the fifth meeting, the students were treated by gamification based on I Ketimun Emas story for the basic competency 3.7 which was about identifying the objects or images that can be seen in surroundings depending on their shape. For the last meeting, gamification based on Siap Selem story was applied as a teaching media with the same basic competency. Thus, it can be said that 2 meetings applied one basic competency with different stories.

The researcher implemented the procedures of the teaching and learning process by Gros (2007) in implementing the gamified Balinese local stories as a teaching media. There were 4 parts in this procedures namely experimentation, activity, discussion, and reflection. The experimentation was the first stage in the procedure which comprised some practices due to the planning before the study was carried out. Identifying a suitable gamification, creating the lesson plan with an appropriate learning objectives for the students were categized as the experimentation of this study. Furthermore, speaking test was given as the pre-test and posttest whereas the speaking rubric was used to assess the students. Determining gamified Balinese local stories as teaching media was the first step in this stage. After that, the researcher introduced the aim of this research to the teacher and also discussed the basic competencies of the fifth grade English learning based on the syllabus. Three basic competencies namely basic competency 3.3 , 3.4 , and 3.7 were selected as the basis in designing a lesson plan and learning goals for every meeting. Besides, the learning goals was used as the basic consideration in designing the speaking test. The speaking test was made from the question related to the pictures of the story. As the students had prior knowledge about the Balinese stories (in Bahasa or Balinese language), the researcher used the same speaking test in pretest and posttest to see the students' progress in speaking English. Reading theories and articles related to the speaking assessment were needed by the researcher before making the speaking rubric. Next was testing the validity of the speaking rubric. After the process was done successfully, the valid rubric was able to be applied for assessing the students in the third stage.

The second stage of Gross procedure was called as activity. In this study, the process of applying gamification as a teaching media was categorized as the activity. Gamification was implemented by operating and showing it through LCD so the students could see what's being displayed clearly. By clicking the "Start" button first, the gamification was ready to be operated and the story was ready to be read and listened by the students. In the middle of enjoying the story, the researcher also guided the students in translating the meaning of each words. The students played the game together after the narrator of the gamification had finished presenting the plot. Each game was designed with three levels and each level consisted of three sub-levels. At each level, the students will respond to various categories of questions. The questions of the game were associated with the narrative of the gamification.

Implementing the gamified Balinese local stories as a teaching media made the students excited and enjoy the learning process. The students were eager to participate in learning as they faced something different and motivated to learn while playing. It was supported by a study from Setiawan, et al. (2019) which found that educational digital game can create fun learning environment that motivates the students to actively participate in the classroom. Students' participation can be seen from the way they communicate with each other discussing the story and the game that they played in every level. Also, the gamified Balinese local stories successfully attract the students' attention as the nature of young learner that loves colorful objects. It can be 
seen from the way the students were paying full attention when the game was displayed on LCD. Trisanti (2016) also supported that media is a vital element to get the students' attention then stimulate them to learn and involve in learning enthusiastically.

Their engagement also can be seen from the way they lifted their hand vigorously as they wanted to answer the questions. The students were motivated and brave enough to try to express their thought about what they saw in the game. Their confidence was reinforced intuitively. Those positive influences from the use of gamification in the classroom also supported by the previous studies. A study conducted by Seixas et al. (2016) revealed that gamification can successfully create an engagement of the $8^{\text {th }}$ year students of elementary school in Brazil. A related study proposed by Papp (2017) within 2 years of data collection such as observation, pre- and post-test results, students' reflections, and survey results found that students' motivation and engagement at both the primary and college level were improved due to the use of gamification. In another case, for the students of health care studies, Korkeakoski Kirsi \& Siklander Pirkko (2018) found that the use of gamification and other related applications in English course can promote students' engagement, foster language learning and create positive learning. Furthermore, Gafni, Achituv, \& Eidelman (2018) pointed out that even though the exam grades after being treated with gamification were not extensively different between the groups, the motivation to learn and continue learning after the experience was higher in the group using gamification. Still talking about engagement, a study proposed by De Paepe et al. (2019) found that there is a positive influence of gamification towards elementary pupils' English learning outcomes and engagement. It could be seen from the experimental group treated by gamification achieved higher score (20.65) than the group without being treated with gamification (19.16). The engagement of the experimental group was also higher than the control group. Comparing the effect of gamification in the present study to the previous studies, it can be clearly seen that gamification successfully engage and motivate students in the learning process. A boring and stressful learning changed into a fun and meaningful learning through gamification so it establishes a better learning experience (Furdu \& Köse, 2017).

The novelties of this study were in the form of various Balinese stories used in the first until sixth meeting and also the dependent variable where this present study figured out whether the use of gamification as a teaching media can affect student's English skill, especially young learners' speaking skill. The stories were intentionally given in order to enrich students' vocabularies. Vocabulary has an important role in speaking since it makes students easier in expressing their idea if they have sufficient of vocabularies. Džanić \& Pejić (2016) stated that in the primary stage of language learning, young learners absorb the material better if they are taught verbally and completed with fascinating media including pictures, video, drawings and other colorful things. The aforementioned theory supported the implementation of gamification in teaching fifth grade students because gamification provided audiovisual teaching media which meant this media was seeable and hearable for the students (Padmadewi, et.al., 2017). Some exciting illustrations and various characters' voices had also completed the game. Gamification allowed students to learn the correct pronunciation of words. It was supported by theory proposed by Taghizadeh et al. (2015), the implementation of gamification as teaching and learning media can positively promote language acquisition and learning enjoyment.

Flores (2016) stated that gamification allowed the students to not merely distinguishing sounds and recognizing words, but also grasping the words. Grasping the words means comprehending the words meaning. In this case, students were helped to understand the word meaning in the stories and relate it with their daily life. They were given opportunity to ask difficult words and take a note. The students did not need an extensive explanation since they already had prior knowledge towards the stories. It affected students' ability in understanding the 
stories since the stories were relatable to their life. The aforementioned statement was supported by Imaniah, Nargis, \& Tangerang (2018) which stated that local stories could help young learners learn language authentically. The moral value of the stories were directly delivered during the learning and teaching process.

The third step was the discussion. The students were given an opportunity to apply what they had learnt previously. After the game had ended, the students were tested by speaking test. It aimed to determine whether they could achieve the learning objective or not. The speaking test was in the form of picture-based questions that related to the topic. The selected scenes of picture were captured from the story in gamification. Those selected pictures had been adjusted with the topic discussed. The measurement of students' speaking skill was conducted by giving the students questions. They were asked to describe the pictures with their own understanding. The assessment of speaking was based on assessment rubric that had been developed.

The speaking test result showed a substantial improvement towards students' confidence in speaking compared to when they had not received the treatment. The pretest and posttest questions were same, however students found difficulties in the pretest due to the lack of vocabulary and the fear of making mistakes. After implementing gamification as teaching media, the students were able understand the question, construct the sentences and describe the picture appropriately in English. This result was in accordance with the result of study conducted by Alfulaih \& Elsayed (2018), that gamification positively affected Saudi EFL learners' enthusiast and confidence in speaking. The significant effect of gamified Balinese local stories on young learners' speaking skill was proved from the difference of before and after treatment mean score.

The last step that had been done was reflection. Reflection aimed at giving the students chance to conclude and reflect on what they had learned throughout the learning activity. It included the name of characters and the plot of story. The moral values from the stories were emphasized and related to students' real life. Local story provided educable values that could be learnt by the students, particluarly they could differentiate positive and negative behavior showed in the stories. Since gamification based on Balinese local stories directly involved students in learning through playing game, students has successfully comprehended and concluded the material. Lee (2015) argued that gamification is a suitable teaching media for young learners because young learners could grasp and comprehend the learning material better through something that they could see, hear, touch and interact with.

After experimentation, activity, discussion and reflection had been done, the data were analyzed descriptively and inferentially. From the six days treatments, the average score of pretest was 69.97 meanwhile the average score of the posttest was 79.95. That finding revealed that the students achieve a better result after the treatments. Besides, the result of inferential analysis presented a significant effect of gamified Balinese local stories as a teaching media on students' speaking skill. The value of Sig (2-tailed) that could be seen from Table 4 was .000 and it was lower than the standard alpha level $(\alpha=.05)$. According to the standards in determining a significant difference, it revealed that the difference of the average score between pretests and posttests was significant and the null hypothesis $\left(\mathrm{H}_{0}\right)$ was rejected. Therefore, the alternative hypothesis $\left(\mathrm{H}_{\mathrm{a}}\right)$ of this study that "there is a significant effect of gamified Balinese local stories as teaching media towards young learners' speaking skill" was accepted.

However, the researcher confronted several challenges in conducting this study, First, the noisy situation happened when all the students getting curious and enthusiastic to play the game directly on researcher's laptop. The researcher decided to use laptop due to the school's rule that did not allow the students to bring their cellphone so the students could not play the game individually. So, the game was operated in a laptop that was placed in front of the class and displayed 
94 JINOTEP (Jurnal Inovasi dan Teknologi Pembelajaran) Kajian dan Riset dalam Teknologi Pembelajaran Vol.7, No.2, Oktober 2020, Hal.86-95

through LCD. For the solution, the researcher gave the students an equal opportunity to operate the game. Second, the students were hard to understand all the sentences in the story because some of the vocabularies were not commonly heard by them. Then, translating the difficult words and giving them the example related to real-life became the solution to this problem and assist the students to understand more about the meaning of those vocabularies.

\section{CONCLUSION}

By giving the treatments, it could be found that gamified Balinese local stories gives a significant effect on students' speaking skill. It was also revealed from the result of descriptive and inferential statistical analysis. In line with the finding of descriptive analysis, the average score of the pre-test was 69.97 and the average score of the post-test achieved 79.95. By looking at the average score, it can be known that the average score of the posttest was higher than the average score of pretests. It showed that gamified Balinese local stories gives a significant effect on fifth-grade students' speaking skill as the score after treatment was higher than the score before treatment.

Also, the result of inferential analysis presented the value of Sig (2-tailed) that could be seen from Table 4 was .000 and it was lower than the standard alpha level $(\alpha=.05)$. According to the standards in determining a significant difference, it revealed that the difference of the average score between pretests and posttests was significant and the null hypothesis $\left(\mathrm{H}_{0}\right)$ was rejected. Therefore, the alternative hypothesis $\left(\mathrm{H}_{\mathrm{a}}\right)$ of this study that "there is a significant effect of gamified Balinese local stories as teaching media towards young learners' speaking skill" was accepted.

\section{REFERENCES}

Alfulaih, W., \& Elsayed, F. A. (2018). The Impact of Using Games On Developing Saudi Female EFL Students ' Speaking Skills Kingdom of Saudi Arabia Ministry of Education Al-Imam Muhammad Ibn Saud Islamic University College of Languages and Translation Department of English Language and Literatu. March.
Bakhsh, S. A. (2016). Using Games as A Tool in Teaching Vocabulary to Young Learners. English Language Teaching, 9(7), 120. https://doi.org/10.5539/elt.v9n7p120

Cameron. (2002). Teaching Languages to Young Learners. L. Cameron. ELT Journal, 56(2), 201-203. https://doi.org/10.1093/elt/56.2.201

Da Rocha Seixas, L., Gomes, A. S., \& De Melo Filho, I. J. (2016). Effectiveness of Gamification In the Engagement of Students. Computers in Human Behavior, 58 , 48-63. https://doi.org/10.1016/j.chb.2015.11.021

De Paepe, A. E., Sierpowska, J., Garcia-Gorro, C., Martinez-Horta, S., Perez-Perez, J., Kulisevsky, J., Rodriguez-Dechicha, N., Vaquer, I., Subira, S., Calopa, M., Muñoz, E., Santacruz, P., Ruiz-Idiago, J., Mareca, C., de Diego-Balaguer, R., \& Camara, E. Ogo-Chukwu, (2019). Gamification Influence On Elementary Pupils' Learning Outcomes and Engagement In English Language. Journal of Chemical Information and Modeling, 53(9), 1689-1699. https://doi.org/10.1017/CBO9781107415324 .004

Derakhshan, A., \& Davoodi Khatir, E. (2015). The Effects of Using Games on English Vocabulary Learning. Journal of Applied Linguistics and Language Research, 2(3), 39-47. www.jallr.ir

Džanić, N. D., \& Pejić, A. (2016). The Effect of Using Songs On Young Learners and Their Motivation for Learning English. NETSOL: New Trends in Social and Liberal Sciences, 1(2), 40-54. https://doi.org/10.24819/netsol2016.8

Furdu, I., \& Köse, U. (2017). Pros and Cons Gamification and Gaming in Classroom. July.

Gafni, R., Achituv, D. B., \& Eidelman, S. (2018). The Effects of Gamification Elements In ELearning Platforms. Online Journal of Applied Knowledge Management, 6(2), 3753.

http://www.iiakm.org/ojakm/articles/2018/v olume6_2/OJAKM_Volume6_2pp37-53.pdf

García, L. A., \& Alvaro, B. T. (2017). Gamification in English Teaching in Primary Education Resumen. Thesis.

Gros, B. (2007). Digital Games in Education: Design of Games-based Learning Environments. Journal of Research on Technology in Education, 40(1), 23-38. https://doi.org/10.1080/15391523.2007.1078 2494

Gudu, B. (2015). Teaching Speaking Skills In 
English Language Using Classroom Activities in Secondary School Level in Eldoret Municipality. Journal of Education and Practice, 6(35), 63.

Imaniah, I., Tangerang, U. M., Nargis, N., \& Tangerang, U. M. (2018). Teaching English for Young Learners (C) 2017 (Issue September).

Korkeakoski Kirsi \& Siklander Pirkko. (2018). Enhancing Engagement, Enjoyment and Learning Experiences by Gamification On An English Course for Healthcare Students. Seminar.Net, 14(1), 13-30. https://doi.org/https://journals.hioa.no/index. php/seminar/article/view/2579

Lee, L. (2015). Digital Media and Young Children 's Learning: A Case Study of Using iPads in American Preschools. 5(12), 12-15. https://doi.org/10.7763/IJIET.2015.V5.643

Leong, L.-M., \& Ahmadi, S. M. (2017). An Analysis of Factors Influencing Learners' English Speaking Skill. International Journal of Research in English Education, 2(1), $34-41$ https://doi.org/10.18869/acadpub.ijree.2.1.3 4

Mattarima, K. (2011). The Teaching Constraints of English as A Foreign Language in Indonesia: The Context of School Based Curriculum. 4(2), 287-300.

Mekler, E. D., Brühlmann, F., Tuch, A. N., \& Opwis, K. (2017). Towards Understanding The Effects of Individual Gamification Elements On Intrinsic Motivation and Performance. Computers in Human Behavior, 71, 525-534. https://doi.org/10.1016/j.chb.2015.08.048

Mert, Y., \& Samur, Y. (2018). Students' Opinions Toward Game Elements Used in Gamification Application. Turkish Online Journal of Qualitative Inquiry, 9(2), 70-101. https://doi.org/10.17569/tojqi.364130

Mohseni Takaloo, N., \& Ahmadi, M. R. (2017). The Effect of Learners' Motivation on Their Reading Comprehension Skill: A Literature Review. International Journal of Research in English Education, 2(3), 10-21. https://doi.org/10.18869/acadpub.ijree.2.3.1 0

Nitiasih, P. K., Budiarta, L. G. R., \& Mahayanti, N. W. S. (2020). Gamifying Balinese Local Story: Facilitating Gen $Z$ in Learning English. 394(Icirad 2019), 234-239. https://doi.org/10.2991/assehr.k.200115.038

Padmadewi, N., Agustini, D., \& Artini, L. (2017).
Pengantar Micro Teaching. Malang: Rajagrafindo Persada.

Papp, T. A. (2017). Gamification Effects On Motivation and Learning: Application to Primary and College Students. International Journal for Cross-Disciplinary Subjects in Education (IJCDSE), 8(3), 3193-3201. https://infonomics-society.org/wpcontent/uploads/ijcdse/publishedpapers/volume-8-2017/GamificationEffects-on-Motivation-and-Learning.pdf

Riegel, C., \& Mete, R. (2017). Educational Technologies for K-12 Learners: What Digital Natives and Digital Immigrants Can Teach One Another. Educational Planning, 24(4), 49-58.

Setiawan, A., Praherdhiono, H., \& Suthoni, S. (2019). Penggunaan Game Edukasi Digital Sebagai Sarana Pembelajaran Anak Usia Dini. JINOTEP (Jurnal Inovasi Dan Teknologi Pembelajaran) Kajian Dan Riset Dalam Teknologi Pembelajaran, 6(1), 3944.

https://doi.org/10.17977/um031v6i12019p03 9

Singh, A. (2014). Challenges and Issues of Generation Z. IOSR Journal of Business and Management, 16(7), 59-63. https://doi.org/10.9790/487x-16715963

Stickel, L. H. (2017). Digital Natives and Digital Immigrants: Exploring Online Harassment Victimization By Generational Age. International Journal of Cyber Criminology, 11(1), 39-62. https://doi.org/10.5281/zenodo.495771

Taghizadeh, M., Street, H., Square, R., Vaezi, S., Street, H., Square, R., Ravan, M., Street, H., \& Square, R. (2015). Digital Games, Songs and Flashcards and their Effects on Vocabulary Knowledge of Iranian Preschoolers. 156-171.

Trisanti, N. (2016). English Digital Talking Books As Media to Teach Narrative Writing. Journal of English Language Teaching, $5(2), 1-8$.

Ur, P. (1996). A Course in Language Teaching. Cambridge: Cambridge University Press.

Zichermann, G., \& Cunningham, C. (2011). Gamification by Design: Implementing Game Mechanics in Web and Mobile Apps. [S.l.]: \&quot;O'Reilly Media, Inc.\&quot; 2011.

http://storage.libre.life/Gamification_by_De sign.pdf 